\title{
RESENHA DO LIVRO: INFORMÁTICA E EDUCAÇÃO MATEMÁTICA DE AUTORIA DE MARCELO DE CARVALHO BORBA E MIRIAM GODOY PENTEADO
}

\author{
Nathália de Melo Azevedo ${ }^{1}$
}

A respectiva obra faz parte da coleção Tendências em Educação Matemática. Voltada para futuros professores e para profissionais da área da Informática que buscam, de diversas formas refletir sobre a Educação Matemática, tendo como princípio que todos podem produzir Matemática, nas suas diferentes expressões apresentando tópicos em Matemática que tenham desenvolvimentos substanciais nas últimas décadas e que podem se transformar em novas tendências curriculares dos ensinos fundamental, médio e universitário.

Seus autores atuam na UNESP de Rio Claro/SP como professores de informática e educação matematica. Articulam propostas de pesquisas e programas de informática nas escolas do Ensino Fundamental e Médio junto ao grupo de pesquisa em informática e outras mídias de Educação Matematica (GPIMEM) que foi fundado em 1993 por eles e pela aluna Telma Gracias.

É um trabalho em conjunto dos autores na área de informática educativa sobre o seu uso no ambiente escolar. Debatendo os temas ligados às políticas governamentais e questões epistemológicas e pedagógicas, relacionadas a utilização de computadores e calculadoras gráficas na Educação Matemática.

No primeiro capítulo apresentam alguns programas governamentais para as escolas brasileiras do Ensino Fundamental e Médio, argumentando sobre a importância de sua articulação, vista como essencial para que seja alcançado o potencial que a informática tem a oferecer para a educação, que são desenvolvidas em ações isoladas por escolas e universidades.

Os diversos programas governamentais promoveram ações em nível nacional estimulando e implementando o uso de tecnologias informáticas nas escolas brasileiras.

\footnotetext{
${ }^{1}$ Licencianda em Matemática pelo Instituto Federal de Educação, Ciência e Tecnologia do Sudeste de Minas - Campus Rio Pomba (IFET), Rio Pomba, Minas Gerais, Brasil. E-mail: nathaliaazevedo1919@gmail.com
} 
DOI: http://dx.doi.org/10.33238/ReBECEM.2019.v.3.n.1.21897

Com o I Seminário Nacional de Informática Educativa, em 1981, surgiram pelo MEC e pela Secretaria Especial de Informática, diversos programas como: EDUCOM, FORMAR E PRONINFE.

O EDUCOM (Computadores na Educação) criou centros pilotos em universidades brasileiras para desenvolver pesquisas sobre as diversas aplicações do computador na educação.

O projeto FORMAR (Programa de Ação Imediata em Informática na Educação), surgiu dentro do EDUCOM, capacitando profissionais para trabalhar na área de informática educativa, criando assim, os CIEDs (Centros de Informática Educacional).

O PRONINFE (Programa Nacional de Informática na Educação) deu continuidade às iniciativas anteriores, contribuindo especialmente para a criação de laboratórios e centros para a capacitação de professores.

Através das experiências anteriores, foi criado o PROINFO (Programa Nacional de Tecnologia Educacional), que é o atual programa do governo, que incentiva a implementação da informática nas escolas de todo o país.

No segundo capítulo, apresentam alguns exemplos oriundos de estudos e pesquisas realizadas pelos autores e o grupo de pesquisa (GPIMEM), evidenciando como a informática pode ser inserida em situações de ensino e aprendizagem da matemática.

Ilustram como os temas de funções podem ganhar uma nova perspectiva quando computadores e calculadoras gráficas tornam-se atores no cenário de sala de aula. Essa forma de tratar a tecnologia, está relacionada com seus posicionamentos sobre o papel das mídias no processo de construção de conhecimento, baseando-se na informática como perspectiva teórica que utilizam para pensar na relação existente entre seres humanos e computador.

No terceiro capítulo, aprofundam teoricamente, a compreensão dos exemplos discutidos no capítulo anterior e apresentam outros exemplos sobre o tema de funções, questionando o lugar do computador em práticas educativas envolvidas no ensinoaprendizagem, professores e pesquisadores envolvidos em tais práticas.

Entende-se que uma perspectiva teórica pode se tornar importante para aqueles que querem exercer investigações na informática na área da educação matematica, visto que, devem buscar a articulação com o tema investigado, para que não tenham incoerência, essencialmente para aqueles que estejam voltados para o cotidiano escolar. 
Esses estudos, podem servir de orientação para que o computador não seja utilizado somente como um instrumento para aprimorar o resultado em um dado teste local, regional ou nacional. É preciso que a chegada de uma mídia qualitativamente diferente, como a informática, contribua para modificar as práticas do ensino tradicional vigente.

Enfatizam ainda, que a inclusão da mídia informática nas escolas não é a libertação dos problemas pedagógicos, e também sua chegada, não paralisa seu debate na prática docente. Mas pode ser inserida como ensino e aprendizagem, contribuindo para as experimentações, visualizações, simulações e não apenas para exemplificar o conteúdo dado. Unindo o conhecimento teórico através do uso das tecnologias informáticas, gerando novas observações, incentivando a interdisciplinaridade sobre conteúdos estudados, proporcionando uma expansão de conhecimentos no desenvolvimento da cidadania.

As investigações matemáticas ligadas à modelagem, seria uma prática mais adequada em consonância com a visão de conhecimento, possuindo alguma dependência em relação ao sujeito, valorizando o processo e não o resultado final.

As novas mídias, como os computadores, softwares gráficos e calculadoras gráficas, permitem aos alunos, aprendizados semelhantes que fazem nas aulas experimentais, trazendo naturalmente a visualização para o centro da aprendizagem matemática, enfatizando a sua importância na atuação pedagógica.

Entende-se que os PCNs (Parâmetros Curriculares Nacionais) têm dado ênfase na interdisciplinaridade e os problemas abertos estão em harmonia com a mídia Informática. No entanto, a tecnologia não pode substituir os professores, com sua implantação no ambiente escolar, o professor adquire mais destaque.

O quarto capítulo é exposto às implicações do uso das TIC's (Tecnologias da informação e comunicação) na prática docente, e as possíveis formas de se estabelecer um suporte para a expansão do seu uso.

Acredita-se que o engajamento de professores em rede de trabalho, é uma possibilidade de se expandir, agir e pensar profissionalmente, promovendo mudanças na educação escolar. 
Para que o professor comece a utilizar novas tecnologias, é preciso que ele reflita sobre o assunto, Alguns, mesmo estando insatisfeitos com o ensino atual, não procuram meios para se atualizarem, optando por não utilizá-las em suas aulas.

No quinto capítulo, enfatizam como a informática comunicacional está mudando a própria identidade e natureza das pessoas. As relações presenciais já se encontram com estruturas de apoio virtual, sendo permeadas de interações via- e-mail. Mostram sua fragilidade diante da rapidez das mudanças tecnológicas.

O conhecimento é produzido pela união de seres humanos e mídias. Visto que, somos constituídos por três grandes técnicas que influenciam nosso saber e memória, tais como: oralidade, escrita e informática.

A oralidade é responsável por estender nossa memória; a escrita permite que a memória se prolongue de uma forma diferente da oralidade, consentindo o surgimento da linearidade do raciocínio; e a informática, que é uma nova extensão da memória, admite que a sequência de pensamentos e ações seja desafiada por meios diferentes baseados em vários aspectos.

No sexto capítulo, relatam sobre a necessidade da presença dos computadores e da internet nas escolas públicas, para a consolidação de um projeto que democratize o país marcado pelo autoritarismo. Nas escolas, a alfabetização informática precisa ser considerada como algo tão importante quanto as demais disciplinas. Consideram fundamental a implementação dos programas que facilitam o acesso à informática, e se mostram entusiasmados com as mudanças que as novas mídias provocam.

Segundo eles, sempre há uma mídia envolvida na produção do conhecimento, e a informática deve ser acessível a todos como um direito a alfabetização tecnológica. Sendo incluída aos estudantes nas escolas públicas e particulares, explorando no ambiente informatizado o conhecimento produzido, a demanda para o trabalho do professor e outras possibilidades educacionais que podem ser discutidas.

$\mathrm{O}$ educador matemático deve estar atento às mudanças que acontecem com o surgimento de novas mídias, lembrando que, ao usar a informática, as demais mídias não precisam ser descartadas.

No final deste exemplar encontra-se um apêndice de sites sobre materiais envolvendo pesquisas investigativas e softwares matemáticos, e ainda, as bibliografias utilizadas pelos autores na construção de suas ideias e outros títulos da coleção. 
DOI: http://dx.doi.org/10.33238/ReBECEM.2019.v.3.n.1.21897

Este livro contribui na ampliação de conhecimentos para futuros professores e docentes na área que pensam e questionam os aspectos mais amplos de políticas ligadas à informática, sendo um estímulo para o aprofundamento em alguns temas mais específicos do cotidiano das aulas de matemática. Se dirige ainda para aqueles que ainda não estão familiarizado com a informática em sua docência e para aqueles que gostariam de conhecer a visão particular dos autores.

\section{Referências}

BORBA, M. C.; PENTEADO, M. G. Informática e educação matemática. 5. ed. Belo Horizonte: Autêntica, 2016.

Recebido em: 07 de março de 2019.

Aceito em: 24 de abril de 2019. 